\title{
RANCANGBANGUN PROTOTIP DOSIMETER BERBASIS KALORIMETRI GRAFIT UNTUK PENGUKURAN DOSIS RADIASI ELEKTRON
}

\author{
Slamet Santosa, Sudjatmoko \\ Pusat Teknologi Akselerator dan Proses Bahan - BATAN \\ Jl. Babarsari Kotak Pos 6101 ykbb, Yogyakarta 55281
}

Diterima 14 Mei 2008, diterima dalam bentuk perbaikan 28 Mei 2009, disetujui 15 Juni 2009

\begin{abstract}
ABSTRAK
RANCANGBANGUN PROTOTIP DOSIMETER BERBASIS KALORIMETRI GRAFIT UNTUK PENGUKURAN DOSIS RADIASI ELEKTRON. Telah dilakukan rancangbangun prototip dosimeter berbasis kalorimetri grafit untuk pengukuran dosis radiasi elektron pada energi elektron sampai dengan $300 \mathrm{keV}$ dan dosis maksimum $60 \mathrm{kGy}$. Inti grafit berbentuk silinder dengan diameter dan ketebalan masing-masing $30 \mathrm{~mm}$ dan $2 \mathrm{~mm}$, dikelilingi pelindung dari bahan grafit yang sama. Dosimeter berbasis kalorimetri dilengkapi Styrofoam untuk isolator panas, sensor suhu dan sistem instrumentasi berbasis mikrokontroler. Karakteristik dosimeter didapatkan dengan perhitungan dan simulasi komputer menggunakan perangkat lunak Penelope 2003 dan program ANSYS. Dosimeter berbasis kalorimetri grafit dirancang untuk memberikan hasil pengukuran dosis serap rata-rata dan dosis permukaan pada grafit secara waktu nyata dan dapat bekerja seperti yang diharapkan. Dibandingkan dengan pengukuran dosis menggunakan dosimeter cellulose tri acetate (CTA), didapatkan perbedaan relatif 18,9\% dan 9,1\% pada masing-masing percobaan dengan variasi energi dan perubahan arus berkas elektron dari mesin berkas elektron (MBE).
\end{abstract}

Kata kunci: Dosimeter, kalorimeter grafit, simulasi komputer, pengukuran dosis radiasi.

\begin{abstract}
ENGINEERING DESIGN OF DOSIMETER PROTOTYPE BASED ON GRAPHITE CALORIMETRY FOR ELECTRON RADIATION DOSE MEASUREMENT. The engineering design of a dosimeter prototype based on graphite calorimetry for electron radiation dose measurement at electron energy of at most $300 \mathrm{keV}$ and maximum dose of $60 \mathrm{kGy}$ have been carried out. The graphite core is a cylinder shape with diameter and thickness of $30 \mathrm{~mm}$ and $2 \mathrm{~mm}$ respectively, surrounded by a guard ring made of the same graphite material. Dosimeter based on graphite calorimetry is equipped with a styrofoam for thermal insulation, temperature sensors and instrumentation based on microcontroller. The characteristics of dosimeter based on graphite calorimetry are obtained by means of calculation and computer simulations using Penelope 2003 software and ANSYS computer program. The dosimeter based on graphite calorimetry has been designed to perform real time measurement of the average of absorbed and surface dose, it was expected that dosimeter based on graphite calorimetry can operate well. Compared with the cellulose tri acetate (CTA) dose measurement it gives relative differences of $18.9 \%$ and $9.1 \%$ at the experiments of energy variation and electron beam current alteration of the electron beam machine (EBM) respectively.
\end{abstract}

Keywords: dosimeter, graphite calorimeter, computer simulation, radiation dose measurement.

\section{PENDAHULUAN}

$D$ ewasa ini penggunaan mesin berkas elektron (MBE) di bidang industri dan kesehatan untuk proses iradiasi bahan semakin meningkat seiring dengan berkembangnya teknik-teknik baru terkait dengan proses iradiasi. Pada setiap penggunaan MBE untuk kepentingan penelitian maupun proses iradiasi pada suatu industri, memerlukan dosimeter sebagai alat ukur besarnya dosis radiasi yang diterima oleh bahan. Hal tersebut dikarenakan dosis radiasi merupakan salah satu parameter kendali mutu proses iradiasi (1). Dosimeter yang lazim digunakan di berbagai fasilitas MBE, yang juga digunakan di PTAPB-BATAN Yogyakarta, adalah dosimeter Cellulosa Triacetat (CTA). Pengukuran dosis menggunakan dosimeter CTA memiliki beberapa kelemahan di antaranya hanya dapat digunakan untuk sekali pengukuran, memerlukan kalibrasi pada setiap pengukuran, diperlukan waktu tenggang 2 jam sejak berakhirnya proses iradiasi dan tidak dapat dilakukan secara waktu nyata (real time). Pada beberapa aplikasi, penggunaan dosimeter CTA sudah mencukupi, tetapi untuk proses iradiasi 
dengan dosis yang relatif lebih besar dan memerlukan pengendalian dosis selama proses iradiasi, dosimeter CTA tidak dapat digunakan.

Salah satu metode pengukuran dosis lain yang dapat digunakan sebagai alternatif pengganti CTA adalah metode kalorimeter. Dengan metode ini pengukuran dosis dapat dilakukan secara waktu nyata dan dapat dihubungkan dengan komputer (PC), sehingga pembacaan dan kalibrasinya dapat dilakukan menggunakan perangkat lunak, serta memungkinkan untuk dikembangkan sebagai pengendalian dosis pada suatu proses iradiasi. Prinsip pengukuran dosis dengan metode kalorimeter adalah memanfaatkan salah satu akibat interaksi elektron dengan bahan, yaitu terjadinya serapan energi yang menyebabkan kenaikan suhu pada bahan, yang besarnya sebanding dengan dosis iradiasinya (2).

Pada penelitian ini dilakukan rancangbangun prototip dosimeter berbasis kalorimeter menggunakan inti grafit untuk pengukuran dosis radiasi elektron dengan energi berkas sampai $300 \mathrm{keV}$ dan dosis maksimum $60 \mathrm{kGy}$. Karakteristik dosimeter yang dirancangbangun didapatkan dari proses interaksi berkas elektron dengan inti grafit secara simulasi menggunakan perangkat lunak Penelope 2003(3), sedangkan waktu tunda terhadap kesetimbangan panas disimulasi menggunakan perangkat lunak ANSYS versi $5.4{ }^{(4)}$. Dosimeter berbasis kalorimeter terdiri dari inti (absorber) grafit berderajat nuklir yang dilingkupi pelindung dari bahan grafit yang sama, isolator panas dari bahan styrofoam, sensor panas dan sistem instrumentasi berbasis mikrokontroler. Sensor panas yang digunakan adalah IC tipe LM35DZ, yang pemilihannya didasarkan pada stabilitas dan linearitas kenaikan suhunya serta besaran dosis maksimum yang dapat diukur. Sistem mikrokontroler yang digunakan adalah tipe AVR ATMega8, dipilih karena mempunyai fitur yang cukup dan harganya murah ${ }^{(5)}$. Dosimeter kalorimeter dilengkapi dengan sistem komunikasi data serial yang dapat dihubungkan ke PC di ruang kontrol MBE dengan jarak 23 meter. Pada dosimeter yang dirancangbangun dibuat dua buah perangkat lunak yang masing-masing untuk mikrokontroler dan komputer (PC). Perangkat lunak mikrokontroler dioperasikan untuk pembacaan data input dari sensor panas dan komunikasi serial menggunakan serial port RS-232, sedangkan perangkat lunak PC dioperasikan untuk perhitungan-perhitungan dan penampil data dosis elektron secara waktu nyata.

\section{METODOLOGI}

\section{a. Dasar Rancangan Dosimeter}

Pada proses iradiasi menggunakan MBE akan terjadi penetrasi elektron ke dalam bahan yang menyebabkan berkurangnya energi kinetik elektron. Interaksi elektron dengan bahan mengakibatkan perpindahan energi, secara makroskopis ditandai dengan kenaikan suhu pada bahan tersebut. Dosimeter dengan metode kalorimeter ini berdasar pada prinsip interaksi elektron dengan bahan inti grafit. Penetrasi elektron pada inti grafit akan menyebabkan terjadinya interaksi antara elektron dengan atom-atom grafit yang menyebabkan elektron kehilangan energinya dan terjadi penambahan energi pada inti grafit. Rata-rata energi yang hilang per jarak tempuh elektron sesuai dengan persamaan sebagai berikut (6).

$$
\frac{d E}{d x}=4 \pi r_{0}^{2} \frac{m c^{2}}{\beta^{2}} N Z\left\{\ln \left(\frac{\beta \gamma \sqrt{\gamma-1} m c^{2}}{I}\right)+\frac{1}{2 \gamma^{2}}\left[\frac{(\gamma-1)^{2}}{8}+1-\left(2 \gamma^{2}+2 \gamma-1\right) \ln 2\right]\right\}
$$

dengan $\frac{d E}{d x}$ adalah rata-rata energi yang hilang per jarak tempuh, $\mathrm{r}_{0}$ jari-jari elektron klasik $=2.818 \times 10^{-15} \mathrm{~m}, \mathrm{mc}^{2}$ $=$ energi diam elektron $=0.511 \mathrm{MeV}$, T energi kinetik electron, $\gamma=1 / \sqrt{1-\beta^{2}}, \beta=v / \mathrm{C}, \mathrm{N}$ jumlah atom per $\mathrm{m}^{3}$ $=\rho \frac{N_{A}}{A}, N_{A}$ bilangan Avogadro $=6.023 \times 10^{23}$ atom $/ \mathrm{mol}, \rho$ densitas bahan, A massa molar bahan, $\mathrm{Z}$ nomor atom bahan dan I potensial eksitasi rata-rata material.

Dosis radiasi adalah dosis serap $D(\mathrm{~J} / \mathrm{kg})$ yaitu besar energi elektron $E(\mathrm{~J})$ yang diserap oleh bahan per satuan massa $\mathrm{m}(\mathrm{kg})$, yang dapat dinyatakan dengan persamaan sebagai berikut (2).

$$
D=\frac{E}{m}
$$


Pada dosimeter dengan metode kalorimeter menggunakan inti grafit penambahan energi yang terjadi pada inti grafit secara makroskopis ditandai dengan bertambahnya suhu. Energi total yang diterima oleh inti grafit akibat interaksi dengan elektron dapat dituliskan dengan persamaan sebagai berikut (8).

$$
\int d E=k m \int C_{p} d T
$$

karena energi serap elektron adalah $D=E / m$ maka dosis serap pada bahan absorber grafit dapat dinyatakan dengan persamaan sebagai berikut,

$$
\int d D=k \int C_{p} d T
$$

dengan $T$ adalah suhu absorber $(K), C_{p}$ kapasitas panas inti grafit (J/kg.K), E energi terdeposisi pada grafit $(\mathrm{J}), \mathrm{k}$ faktor koreksi, m massa grafit $(\mathrm{kg})$ dan D dosis serap $(\mathrm{J} / \mathrm{kg})$. Lebih lanjut, berkas elektron yang datang dari suatu MBE mengenai inti grafit menyebabkan transformasi energi yang kemudian diubah menjadi panas sehingga dosis serap rata-rata dapat dinyatakan sebagai berikut ${ }^{(7)}$,

$$
D=\frac{Q}{m}=\frac{m \cdot C_{p} \cdot \Delta T}{m}=C_{p} \cdot \Delta T
$$

dengan $\mathrm{Q}$ adalah energi elektron yang diubah menjadi panas.

Kapasitas panas spesifik grafit sebagai bahan absorber adalah besaran yang berubah secara parabolik terhadap perubahan suhu. Untuk suhu operasi antara $273 \leq T \leq 333(\mathrm{~K})$ atau $0-60{ }^{\circ} \mathrm{C}$ hubungan antara perubahan suhu dan kapasitas termal grafit mengikuti persamaan sebagai berikut $(8,9)$,

$$
C_{p}=-0,0011 T^{2}+3,25 T-163
$$

Untuk suhu operasi antara $334 \leq T \leq 3000(\mathrm{~K})$ atau $61-2727^{\circ} \mathrm{C}$ perubahan tersebut lebih kompleks, mengikuti persamaan sebagai berikut,

$$
\begin{aligned}
C_{p}= & 8,1353 \times 10 T^{-2}-6,2119 \times 10^{5} T^{-1}+1289,2+2,6326 T-2,5559 \times 10^{-3} T^{2} \\
& +1,2376 \times 10^{-6} T^{3}+2,9593 \times 10^{-10} T^{4}+2,7904 \times 10^{-14} T^{5}
\end{aligned}
$$

dengan $C_{p}$ adalah kapasitas panas spesifik bahan grafit berderajat nuklir (J/kg.K).

Parameter lain yang signifikan dalam desain dosimeter berbasis kalorimeter adalah dosis permukaan Bentuk fisik CTA adalah berupa lembaran bening dengan masa jenis $1,289 \mathrm{~g} / \mathrm{cm}^{3}$ dan memiliki ketebalan $1,25 \times 10^{-2}$ $\mathrm{cm}$. Pada pengukuran dosis, dilakukan dengan meletakkan CTA di permukaan bahan, sehingga dosis radiasi yang terukur pada CTA adalah dosis permukaan (surface dose). Hubungan antara dosis serap rata-rata dan dosis permukaan dinyatakan dengan persamaan sebagai berikut ${ }^{(10)}$,

$$
k_{s}=\frac{D_{s}}{D_{a v g}}
$$

dengan $k_{s}$ adalah faktor perbandingan antara dosis yang terukur pada permukaan $D_{s}$ dan dosis serap rata-rata $D_{\text {avg }}$ pada dosimeter dengan metode kalorimeter.

\section{b. Simulasi Interaksi Elektron Dengan Inti Dosimeter}


Pada simulasi ini dilakukan pemodelan proses iradiasi MBE menggunakan rutin PENCYL dari program PENELOPE 2003 (3,11). Sebagai target iradiasi digunakan bahan grafit dengan spesifikasi yang sama seperti bahan inti dosimeter. Rutin PENCYL sebelumnya dikompilasi menggunakan GNUFortran untuk mendapatkan excutable file, yang kemudian dieksekusi dengan berkas masukan yang berisi geometri proses iradiasi MBE dengan format tertentu untuk setiap keadaan yang disimulasikan. Simulasi menggunakan rutin PENCYL menghasilkan tiga berkas keluaran sebagai berikut:

- calorimeter.dat, berisi ringkasan parameter-parameter simulasi

- pcdosch1.dat, berisi distribusi dosis dalam 3 dimensi

- $\quad$ pcddose.dat, berisi data distribusi dosis menurut kedalaman (depth dose)

Dari ketiga berkas masukan tersebut didapatkan data-data yang diperlukan pada perancangan seperti laju dan distribusi dosis secara radial, distribusi dosis kedalaman, jangkau lintasan elektron dan dosis serap rata-rata. Secara umum model geometri dengan jarak inti grafit dari jendela MBE dalam Cm disusun seperti pada Gambar 1, dengan berkas masukan dalam berbagai konfigurasi jarak dan energi berkas elektron.

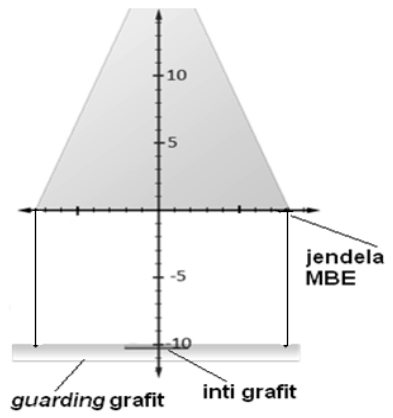

Gambar 1. Model geometri proses iradiasi MBE menggunakan rutin PENCYL

\section{c. Simulasi Perambatan Panas Pada Inti Grafit}

Kenaikan suhu yang disebabkan oleh proses iradiasi berkas elektron pada inti grafit tidak merata karena hanya bagian atas inti grafit yang terkena radiasi berkas elektron secara langsung. Hal ini menyebabkan pada bagian bawah inti grafit, dimana diletakkan sensor suhu mengalami kenaikan suhu lebih lambat daripada bagian atas dan menyebabkan waktu tunda (delay) pada pengukuran besaran suhu. Untuk mengetahui waktu tunda yang diperlukan agar suhu bagian bawah inti grafit sama dengan suhu bagian atas maka dilakukan simulasi dengan perangkat lunak bantu ANSYS versi 5.4 .

\section{d. Pembuatan Perangkat Keras Dosimeter Berbasis Kalorimeter Grafit}

Perangkat absorber grafit terdiri dari inti grafit berbentuk silinder yang dipasangkan dua buah sensor suhu LM53DZ pada bagian belakangnya, guarding grafit untuk mencegah energi panas inti grafit hilang ke arah samping dan kotak styrofoam untuk isolator panas yang juga berfungsi sebagai penyangga inti grafit. Perangkat inti grafit ditunjukkan pada Gambar 2.

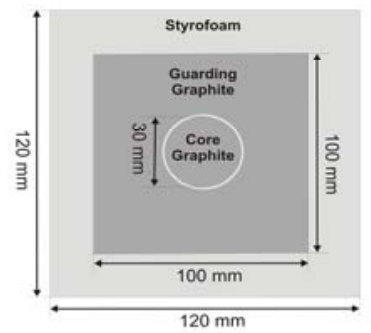

Gambar 2. Perangkat inti grafit tampak atas 
Sistem instrumentasi dosimeter yang dirancangbangun terdiri dari sensor suhu LM35DZ berikut penguat tegangan dengan operational amplifier (OpAmp) LM324 dalam mode non-inverting dan sistem mikrokontroler AVR ATMega8. Rangkaian sensor suhu dan penguat OpAmp ditunjukkan pada Gambar 3, sedangkan rangkaian sistem mikrokontroler adalah rangkaian kit standar yang ditambah rangkaian keluaran RS-232.

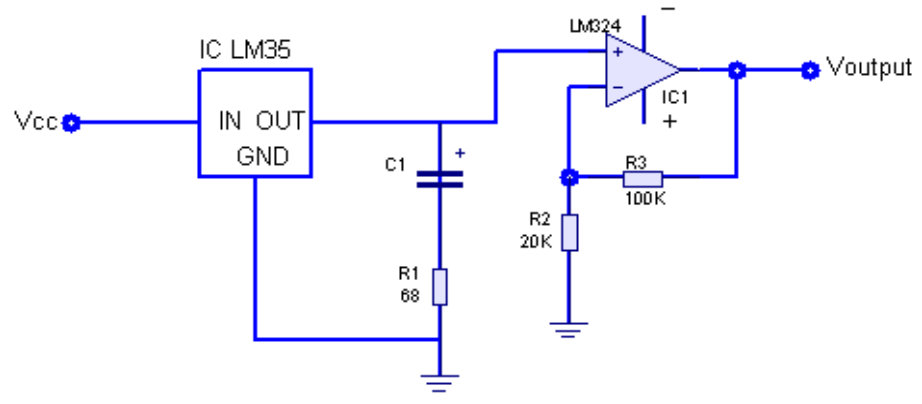

Gambar 3. Rangkaian sensor suhu dan penguat tegangan

\section{e. Pembuatan Perangkat Lunak dan Penampil}

Perangkat lunak dosimeter berbasis kalorimeter grafit terdiri dari dua program, masing-masing program untuk mikrokontroler dan program untuk PC. Program untuk mikrokontroler bekerja berdasar interupsi dari PC, terdiri dari program utama dan beberapa subrutin sehingga mikrokontroler bekerja mulai dari menerima masukan data dari sensor suhu sampai dengan pengiriman data melalui serial port RS-232. Program untuk PC dimulai dengan proses FIFO pada queue untuk mengambil data suhu dan menghitung kapasitas panas (Cp) menggunakan persamaan (6) dan atau (7) dengan mengoperasikan kondisi IF-THEN-ELSE. Keluaran data Cp kemudian digunakan untuk menghitung dosis serap rata-rata. Setelah suhu grafit saat ini diketahui kemudian dibandingkan dengan suhu sebelumnya, bila ada penambahan suhu maka dilakukan perhitungan $\mathrm{Cp}$ berikutnya. Untuk memperoleh besaran dosis permukaan, dilakukan perhitungan menggunakan persamaan (8). Diagram alir perangkat lunak dosimeter yang dirancangbangun ditunjukkan pada Gambar 4.

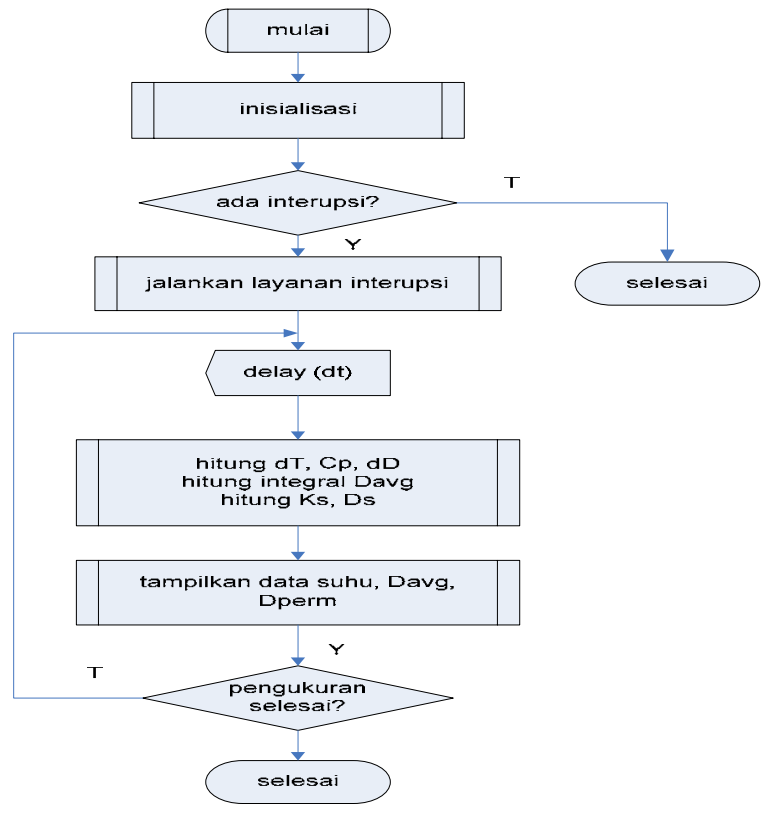

Gambar 4. Diagram alir perangkat lunak dosimeter berbasis kalorimeter grafit 


\section{HASIL DAN PEMBAHASAN}

\section{Karakteristik Dosimeter}

Karakteristik dosimeter berbasis kalorimeter grafit yang dirancangbangun didapatkan dari perhitungan dan simulasi komputer yang meliputi laju dosis, nilai faktor $k_{s}$, jangkau elektron pada inti grafit, maksimum dosis dan kesetimbangan termal.

\section{Laju Dosis}

Hubungan laju dosis dari dosimeter terhadap energi berkas elektron dan jarak target dari jendela MBE ditunjukkan masing-masing pada Gambar 5 dan 6 sebagai berikut.

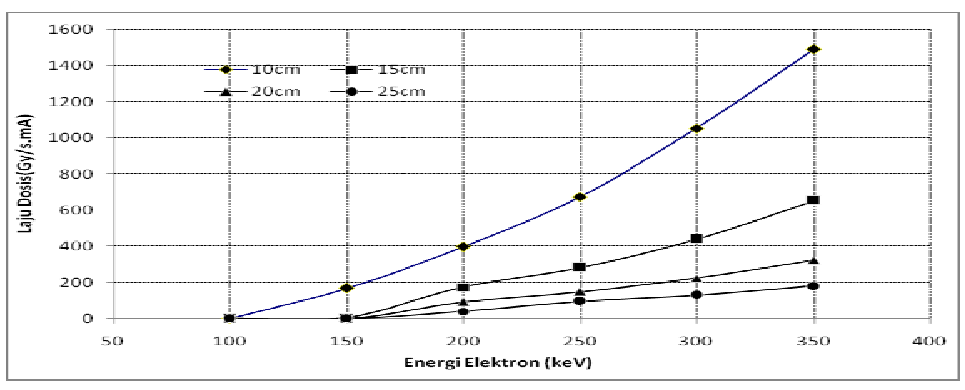

Gambar 5. Laju dosis dosimeter berbasis kalorimeter grafit terhadap energy berkas elektron

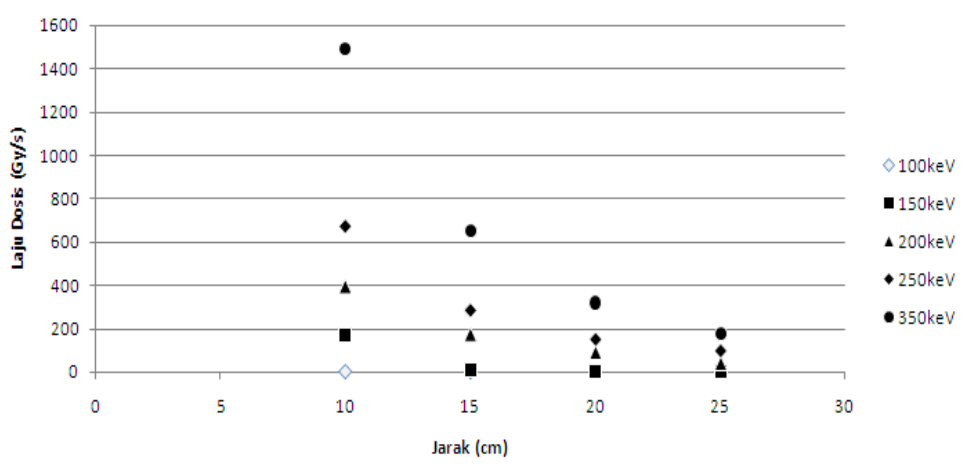

Gambar 6. Laju dosis dosimeter berbasis kalorimeter grafit terhadap jarak dari jendela MBE

\section{Nilai Faktor $\mathbf{k}_{\mathbf{s}}$}

Nilai faktor $k_{s}$ hasil simulasi pada permukaan grafit dan data depth dose terhadap perubahan jarak dan energi berkas elektron diberikan pada Tabel 1 . Faktor ini digunakan untuk menghitung dosis permukaan absorber grafit terhadap nilai dosis serap rata-rata.

Tabel 1. Nilai $k_{s}$ pada inti grafit dosimeter berbasis kalorimeter

\begin{tabular}{|c|c|c|c|c|c|c|}
\hline \multirow{2}{*}{ Jarak (cm) } & \multicolumn{7}{|c|}{$\mathrm{k}_{\mathrm{s}}$} \\
\cline { 2 - 7 } & $100 \mathrm{keV}$ & $150 \mathrm{keV}$ & $200 \mathrm{keV}$ & $250 \mathrm{keV}$ & $300 \mathrm{keV}$ & $350 \mathrm{keV}$ \\
\hline 10 & 0 & 6,96 & 11,3 & 6,76 & 4,39 & 3,08 \\
\hline 13 & 0 & 4,54 & 10,77 & 6,95 & 4,68 & 3,24 \\
\hline 15 & 0 & 4,81 & 9,87 & 7,03 & 4,65 & 3,21 \\
\hline 20 & 0 & 3,37 & 6,65 & 6,61 & 4,83 & 3,57 \\
\hline 25 & 0 & 0 & 1,14 & 0,96 & 0,94 & 0,96 \\
\hline
\end{tabular}




\section{Jangkau Elektron}

Perjalanan elektron menembus dan berinteraksi dengan atom-atom inti grafit menyebabkan elektron kehilangan energi yang dideposit pada inti grafit dan dirubah menjadi panas, yang kemudian dihitung sebagai energi serap. Jangkau elektron hasil simulasi dan perhitungan menggunakan persamaan (1) ditunjukkan pada Gambar 7.

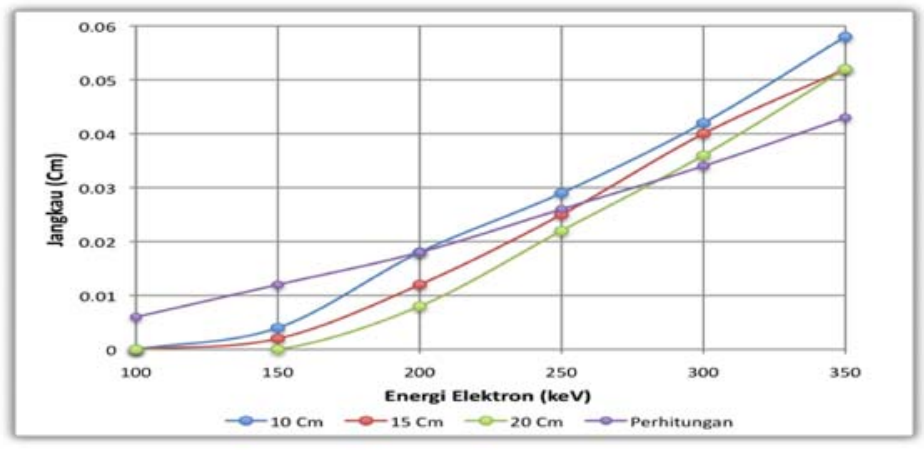

Gambar 7. Jangkau berkas elektron pada inti grafit dosimeter berbasis kalorimeter

Dari jangkau elektron tersebut ditentukan tebal inti grafit yang digunakan setebal $2 \mathrm{~mm}$, sehingga dipastikan bahwa semua energi elektron terserap pada ini grafit.

\section{Maksimum Dosis}

Radiasi elektron yang datang dari MBE mengenai inti grafit menyebabkan transformasi energi yang kemudian diubah menjadi panas. Besar panas yang ditimbulkan berbanding lurus dengan dosis serap rata-rata dan panas tersebut adalah panas yang diderita oleh sensor suhu yang digunakan. Hasil perhitungan menggunakan persamaan (5), (6) dan (7) ditunjukkan pada Gambar 8.

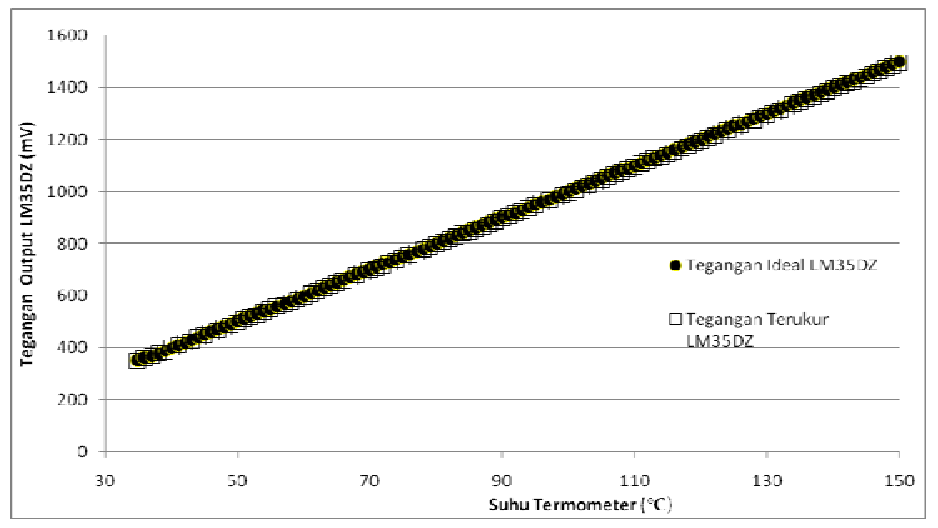

Gambar 8. Karakteristik linearitas sensor suhu LM35DZ

Dari kurva di atas dipastikan bahwa sensor suhu yang digunakan mampu dan masih linear pada suhu operasi $150{ }^{\circ} \mathrm{C}$, namun untuk keamanan sensor ditentukan dosis maksimum yang dapat diukur adalah $60 \mathrm{kGy}$, yang bersesuaian dengan suhu $100{ }^{\circ} \mathrm{C}$.

\section{Kesetimbangan Termal}

Waktu untuk mencapai kesetimbangan termal pada inti grafit dihitung menggunakan program ANSYS versi 5.4. Dengan data masukan spesifikasi bahan absorber grafit, didapatkan data perambatan panas seperti ditampilkan pada Tabel 2. 
Tabel 2. Perbedaan waktu pada kesetimbangan suhu grafit

\begin{tabular}{|c|c|}
\hline$\Delta \mathbf{T}\left({ }^{\circ} \mathbf{C}\right)$ & Waktu rambat panas $(\mathrm{s})$ \\
\hline 5 & 1,529 \\
\hline 10 & 1,646 \\
\hline 15 & 1,660 \\
\hline 20 & 1,714 \\
\hline
\end{tabular}

\section{Pengujian Dosimeter Berbasis Kalorimeter Grafit}

Pengujian dosimeter berbasis kalorimeter dengan inti grafit yang dirancangbangun dilakukan di ruang fasilitas iradiasi MBE PTAPB dan pengukuran dilakukan di ruang kendali pada jarak 23 meter.

\section{Pengujian dengan perubahan energi MBE}

Pengujian dilakukan sebanyak 3 kali dengan parameter-parameter arus berkas elektron $=0,25 \mathrm{~mA}$, waktu iradiasi $=72$ detik $(\mathrm{s})$ dan jarak jendela pemayar dengan kalorimeter $=13 \mathrm{~cm}$ dibuat tetap. Energi MBE dinaikkan sebesar $25 \mathrm{keV}$ pada setiap pengujian. Dosis iradiasi dari hasil pengukuran menggunakan CTA dan menggunakan dosis "permukaan" dari dosimeter berbasis kalorimeter grafit ditunjukkan pada Gambar 9.

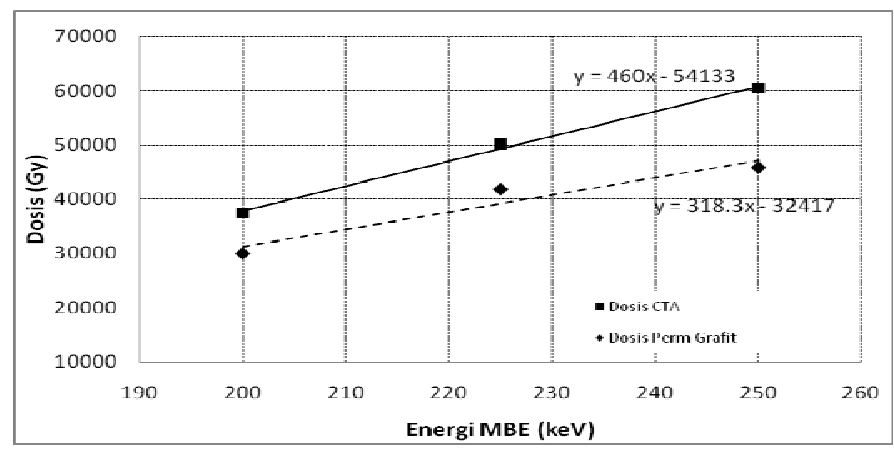

Gambar 9. Pengukuran dosis akibat perubahan energi dengan CTA dan kalorimeter grafit

\section{Pengujian dengan perubahan arus berkas elektron}

Pengujian dilakukan sebanyak 3 kali dengan parameter energi MBE $=250 \mathrm{keV}$, waktu iradiasi $=60$ detik dan jarak jendela dengan kalorimeter $=13 \mathrm{~cm}$ dibuat tetap. Arus berkas elektron dinaikkan sebesar $0,25 \mathrm{~mA}$ pada setiap pengujian. Dosis iradiasi dari hasil pengukuran menggunakan CTA dan dosimeter berbasis kalorimeter grafit ditunjukkan pada Gambar 10.

Dari kedua percobaan pengujian di atas didapatkan bahwa pengukuran menggunakan CTA rata-rata lebih besar daripada pengukuran menggunakan dosimeter berbasis kalorimeter grafit yang dirancangbangun. $\mathrm{Hal}$ tersebut dimungkinkan adanya sebagian panas yang hilang secara konveksi ke arah atas dari inti grafit yang digunakan dan panas tersebut belum diperhitungkan pada perangkat lunak yang dibuat.

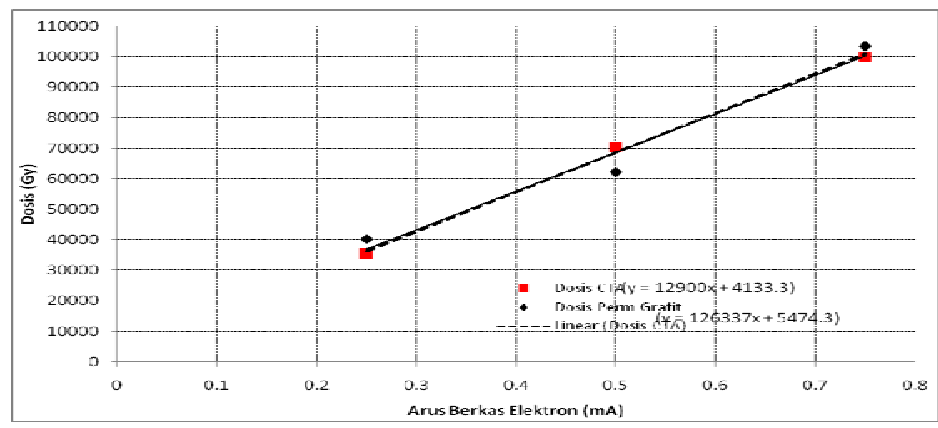

Gambar 10. Pengukuran dosis akibat perubahan arus dengan CTA dan kalorimeter grafit 


\section{KESIMPULAN}

1. Dengan simulasi menggunakan perangkat lunak Penelope 2003 dapat dirancang dosimeter berbasis kalorimeter grafit untuk pengukuran dosis elektron dengan energi sampai $300 \mathrm{keV}$ dan dosis maksimum 60 kGy.

2. Dibandingkan dengan dosis permukaan pada CTA, dosimeter yang dirancangbangun terdapat perbedaan relatif $18,9 \%$ pada percobaan pengukuran dengan variasi energi MBE dan $9,1 \%$ pada percobaan pengukuran dengan variasi arus berkas elektron.

3. Prototip dosimeter berbasis kalorimeter grafit yang dirancangbangun dapat digunakan untuk pengukuran dosis radiasi elektron pada proses iradiasi menggunakan MBE apabila terlebih dahulu dilakukan kalibrasi dengan alat ukur dosis standar.

4. Penggunaan RS-232 pada dosimeter berbasis kalorimeter grafit memungkinkan pengukuran dosis radiasi elektron pada proses iradiasi MBE secara waktu nyata dari ruang kendali MBE pada jarak 23 meter.

5. Prototip dosimeter berbasis kalorimeter grafit yang dirancangbangun memungkinkan untuk dikembangkan sebagai komponen kendali proses iradiasi menggunakan MBE.

\section{DAFTAR PUSTAKA}

1. SABHARWAL SUNIL, Development of Applications of Electron Beam Based Technology, materi BAS-2006, PTAPB - BATAN Yogyakarta, (2006).

2. ALEX F. BIELAJEW, Fundamentals of Radiation Dosimetry and Radiological Physics, The University of Michigan - Department of Nuclear Engineering and Radiological Sciences, (2005).

3. F., SALVAT, PENELOPE, a Code System for MonteCarlo Simulation of Electron and Photon Transport, Universitat de Barcelona, Barcelona, Spain, (2003).

4. ERDOGAN MADENCI at.al., The Finite Element Method and Application in Engineering Using ANSYS, Springer, (2006).

5. ATMEL, "ATMEGA8 Assembler User Guide", Section 4, Rev. 1022A-A-01, (1998).

6. STANLEY HUMPHRIES, Principles of Charged Particle Acceleration, ISBN 0-471-87878-2, (1986).

7. J., HELT HANSEN, Calorimetry for Dose Measurement at Electron Accelerators in the 80-120 keV Energy Range, Radiation and Physics Chemistry 74 (2005) 354-371, Elsevier Ltd., (2005).

8. P.P., PANTA, Specific Heat of Selected Graphites Used in Calorimetry of Electron Beam and Its Influence on the Accuracy of Measurement of Large Dose, Institute of Nuclear Chemistry and Technology, Warszawa, Poland, (2005).

9. ASTM, "Standard Practice for use of calorimetric dosimetry systems for electron beam dose measurements and dosimeter calibrations", (1996).

10. N.M., ALI, F.A., SMITH, N.R., Mc.EWEN, A Real-time Graphite Calorimeter, Malaysian Institute for Nuclear Technology Research, Malaysia.

11. J.M., FERNANDEZ, Tricks \& Tips on The Use of Penelope, Universitat de Barcelona, Barcelona, Spain, (2005). 